\title{
Can blood parameters be used to assess the recovery time of Bell's palsy patients? A retrospective case-controlled study
}

\author{
Bell palsili hastalarda kan parametreleri iyileşme süresini değgerlendirmekte kullanılabilir mi? \\ Retrospektif bir olgu kontrol çalışması
}

Sultan Şevik Eliçora, Duygu Erdem

Department of Otolaryngology, Medical Faculty of Bülent Ecevit University, Zonguldak, Turkey

\section{ABSTRACT}

Objectives: This study aims to investigate if the parameters such as neutrophil-lymphocyte ratio (NLR), mean platelet volume (MPV), platelet count (PLT), plateletcrit (PCT) and platelet distribution width (PDW) can be used to assess the recovery time of Bell's palsy.

Patients and Methods: Between January 2011 and January 2014, a total of 48 patients (22 males, 26 females; mean age $43.5 \pm 22.1$ years; range 3 to 76 years), who were followed up for Bell's palsy for a period of one to three years, and 49 healthy individuals ( 20 males, 29 females; mean age $40.4 \pm 18.2$ years; range 3 to 72 years), for control, were included in the study. NLR, MPV, PLT, PCT and PDW values were measure with an automated blood cell counter. All patients were treated with prednisone. The recovery time of the patients were compared.

Results: The mean PCT, MPV and neutrophil values in patients with Bell's palsy were significantly higher than that of the control group $(\mathrm{p}<0.05)$. The eosinophil values in patients with Bell's palsy were significantly lower than that of the control group $(\mathrm{p}<0.05)$.

Conclusion: Although NLR, PLT, PCT, PDW and MPV values informs us about the etiological aspects, this study shows that they cannot be used as an indicator to predict prognosis or the recovery time.

Keywords: Bell's palsy; idiopathic facial palsy; mean platelet volume; neutrophil-lymphocite ratio; platelet distribution width; plateletcrit.
$\ddot{O} Z$

Amaç: Bu çalışmada nötrofil-lenfosit oranı (NLR), ortalama trombosit hacmi (OTH), trombosit sayısı (PLT), trombosit platetkriti (PCT) ve trombosit dağılım genişliği (PDW) değerlerinin Bell palsisi için iyileşme süresini değerlendirmede kullanılabilirliği araştırıldı.

Hastalar ve Yöntemler: Ocak 2011 - Ocak 2014 tarihleri arasında bir ila üç yıl boyunca Bell palsisi tanısı ile takip edilen 48 hasta ( 22 erkek, 26 kadın; ort. yaş $43.5 \pm 22.1$ yıl; dağılım 3-76 yıl) ve 49 sağlıklı birey (20 erkek, 29 kadın; ort. yaş $40.4 \pm 18.2$ yıl; dağılım 3-72 yıl) kontrol amaçlı çalışmaya dahil edildi. Otomatik kan sayımı cihazı ile NLR, OTH, PLT, PCT ve PDW değerleri ölçüldü. Tüm hastalar prednizolon ile tedavi edildi. Hastaların iyileşme süresi karşılaştırıldı.

Bulgular: Ortalama PCT, OTH ve nötrofil değerleri Bell palsili hastalarda kontrol grubuna kıyasla anlamlı derecede yüksekti $(\mathrm{p}<0.05)$. Eozinofil değerleri Bell palsili hastalarda kontrol grubuna kiyasla anlamlı derecede düşüktü $(\mathrm{p}<0.05)$.

Sonuç: Bu çalışma NLR, PLT, PCT, PDW ve OTH değerleri her ne kadar etyolojik açıdan bize bilgi verse de prognozu ya da iyileşme süresini tahmin etmede belirteç olarak kullanılamaz.

Anahtar sözcükler: Bell palsisi; idyopatik fasiyal palsi; ortalama trombosit hacmi; nötrofil-lenfosit oranı; trombosit dağılımı genişliği; plateletkrit. 
Bell's palsy (idiopathic facial paralysis) is caused by the acute onset of lower motor neuron weakness of the facial nerve with no detectable cause. ${ }^{[1]}$ Retroauricular pain, decreased tolerance to noise and the loss of taste on the same side may accompany these findings.

Bell's palsy is named after Sir Charles Bell (1774-1842), who first described the syndrome along with the anatomy and function of the facial nerve. It affects about $11-40$ people per 100,000 and lifetime risk of contracting the disease is 1 in $60 .{ }^{[2]}$

Despite many studies, the etiology of Bell's palsy has not been clarified yet. Failure of microcirculation in vaso nervosum, ischemic neuropathy, infections, genetic and immunological factors are responsible in the etiology. Viral infections and inflammation play an important role. ${ }^{[3,4]}$

When faced with a patient suffering from Bell's palsy, it is difficult to determine prognosis. Although the most useful tests determining prognosis are considered to be electroneuronography (ENoG) and electromyography (EMG), the accessibility of patients to these machines and the fact that they provide more useful results at specific time intervals, limit the utility of these tests. As a result, to determine prognosis, tests that are easier to perform and access are needed.

Complete blood count (CBC) and its parameters are known as the classic inflammatory markers in cardiovascular and oncological diseases. ${ }^{[5-10]}$ Neutrophil-to-lymphocyte ratio (NLR) has been defined as a novel potential marker to determine inflammation. Mean platelet volume (MPV), plateletcrit (PCT), platelet distribution width (PDW) is shown as a potential marker of thrombosis and inflammation. ${ }^{[7-11]}$ The aim of this study is to investigate whether NLR, MPV, platelet (PLT), PCT, PDW values can be used for the etiopathogenesis of Bell's palsy and the evaluation of recovery time.

\section{PATIENTS AND METHODS}

The present study was conducted at the Department of Otolaryngology, Medical Faculty of Bülent Ecevit University, Zonguldak, Turkey between January 2011 and January 2014. The patient files were scanned; 70 patients, who received follow up due to a Bell's palsy diagnosis for a period of one to three years by otorhinolaryngology clinics, were identified. Twelve patients who did not attend their follow-up appointments were excluded from the study. Forty-eight patients (22 males, 26 females; mean age $43.5 \pm 22.1$ years; range 3 to 76 years) who complained of facial paralysis, who were diagnosed with BP, and visited our department regularly during the first week after diagnosis and during treatment, were enrolled. Patients were compared with a control group of 49 healthy volunteers (20 males, 29 females; mean age $40.4 \pm 18.2$ years; range 3 to 72 years) with similar demographic aspect. The patients were classified according to the House-Brackmann grading system during the pre-treatment and post-treatment periods. During the post-treatment period, the patients with House-Brackmann grade I were regarded as satisfactory recovery, while House-Brackmann grade III to VI were regarded as unsatisfactory recovery, at least one year after follow-up.

Patients were divided into four categories in terms of recovery time as first group who recovered in 0-29 days, second group who in 30-89 days, third group who recovered in 3-6 months, and fourth group who did not recover. The degree of facial paralysis at first visit and recovery times of patients are shown in Table 1 .

The routine pre-treatment $\mathrm{CBC}$ tests of the patients were recorded. Each patient underwent a complete ear, nose and throat examination, neurological examination, audiograms, temporal bone computed tomography or magnetic resonance imaging with gadolinium. Patients with otologic problems, acute or chronic inflammatory

Table 1

Degree of facial paralysis at first visit and recovery times of patients

\begin{tabular}{|c|c|c|c|c|}
\hline & $\begin{array}{l}\text { Group } 1(\mathrm{n}=23) \\
\quad(0-29 \text { day })\end{array}$ & $\begin{array}{c}\text { Group } 2(\mathrm{n}=16) \\
(30-89 \text { day })\end{array}$ & $\begin{array}{c}\text { Group } 3(\mathrm{n}=6) \\
(3-6 \text { month) }\end{array}$ & $\begin{array}{l}\text { Group } 4 \text { ( } \mathrm{n}=3 \text { ) } \\
\text { (non-healing) }\end{array}$ \\
\hline & $\mathrm{n}$ & $\mathrm{n}$ & $\mathrm{n}$ & $\mathrm{n}$ \\
\hline House-Brackmann grade II & 10 & 7 & 1 & 0 \\
\hline House-Brackmann grade III & 8 & 8 & 2 & 0 \\
\hline House-Brackmann grade IV & 3 & 0 & 1 & 1 \\
\hline House-Brackmann grade $\mathrm{V}$ & 2 & 1 & 2 & 2 \\
\hline
\end{tabular}


diseases were excluded. All the patients were treated with corticosteroids (with an initial dose of prednisone of $1 \mathrm{mg} / \mathrm{kg} / \mathrm{day}$, and a gradual dose reduction maintained for at least 2 weeks); acyclovir (in adults $200 \mathrm{mg}$ orally every 4 hours [ 5 times a day] for five days; in children $80 \mathrm{mg}$ per kg daily divided every six hours for five days, with a maximum dose of 3,200 $\mathrm{mg}$ daily). Diabetic patients were hospitalized and the same treatment was applied and insulin was provided for blood sugar regulation. This study was approved by the Medical Faculty of Bülent Ecevit University Hospital Ethic Committee and all participants signed an informed consent agreement.

\section{Hematologic analysis}

An automated blood cell counter was used for CBC measurements (1h 780 Analyzer; Beckman Coulter Inc., Miami, FL, USA). All samples were run in duplicate, and the mean values were used for statistical analysis.

\section{Statistical analysis}

Statistical analyses were performed using PASW version 19.0 software (SPSS Inc., Chicago, IL, USA). Distribution of data was determined by Shapiro-Wilk test. Continuous variables were expressed as mean \pm standard deviation. Deviation and categorical variables as frequency and percentage. Categorical variables were compared using Pearson's chi-square test. Continuous variables were compared with the Mann-Whitney U test for two groups. The Kruskal-Wallis test was used to determine for differences between three groups. $P$ values of less than 0.05 were considered statistically significant for all tests.

\section{RESULTS}

The patient group was between the ages 3-76, the control group between 3-72 years of age. The mean age in the control group was $40.4 \pm 18.2$ and in the Bell's palsy group $43.5 \pm 22.1$. The median age in Bell's palsy group was 48.5 and in the control group it was 42 . The characteristics and the laboratory data of the groups are showed in Table 1.

The mean PLT values of Bell's palsy patients were $270.2 \pm 103.4$ and the control group was $216.1 \pm 46.2$. The mean PLT values in patients with Bell's palsy were significantly higher than the control group $(\mathrm{p}<0.01)$.

The mean PCT values of Bell's palsy patients were $0.222 \pm 0.07$ and the control group was $0.190 \pm 0.36$. The mean PCT values in patients with Bell palsy were significantly higher than the control group $(\mathrm{p}<0.01)$.

The mean PDW values of Bell's palsy patients were $16.54 \pm 0.54$ and the control group was $16.72 \pm 0.47$. The difference was not statistically significant $(p>0.05)$.

The mean MPV values of Bell's palsy patients were $8.48 \pm 1.34$ and the control group was $8.92 \pm 1.13$. The difference was not statistically significant $(p>0.05)$.

The mean neutrophil values of Bell's palsy patients were $6.694 \pm 3.62$ and the control group was $4.53 \pm 1.2$. The mean neutrophil values in patients with Bell's palsy were significantly higher than the control group $(\mathrm{p}<0.001)$.

The mean lymphocy te values of Bell's palsy patients were $2.32 \pm 1.48$ and the control group was $2.05 \pm 0.74$. The difference was not statistically significant ( $>0.05$ ).

Table 2

The characteristics and the laboratory data of the different groups

\begin{tabular}{|c|c|c|c|c|c|c|c|}
\hline & \multicolumn{3}{|c|}{ Bell's palsy patients } & \multicolumn{3}{|c|}{ Controls } & \multirow[b]{2}{*}{$p$} \\
\hline & $\mathrm{n}$ & $\%$ & Mean \pm SD & $\mathrm{n}$ & $\%$ & Mean \pm SD & \\
\hline \multicolumn{8}{|l|}{ Gender } \\
\hline Male & 22 & 46 & & 20 & 41 & & \\
\hline Female & 26 & 54 & & 29 & 59 & & \\
\hline Platelet count & & & $270.21 \pm 103.406$ & & & $216.10 \pm 46.169$ & $0.003^{*}$ \\
\hline Plateletcrit & & & $0.222 \pm 0.07$ & & & $0.190 \pm 0.36$ & $0.008 *$ \\
\hline Platelet distribution width & & & $16.54 \pm 0.54$ & & & $16.72 \pm 0.47$ & 0.057 \\
\hline Mean platelet volume & & & $8.48 \pm 1.34$ & & & $8.92 \pm 1.13$ & 0.146 \\
\hline Neutrophil & & & $6.694 \pm 3.62$ & & & $4.53 \pm 1.2$ & $0.001^{*}$ \\
\hline Lymphocytes & & & $2.32 \pm 1.48$ & & & $2.05 \pm 0.74$ & 0.806 \\
\hline Neutrophil-lymphocyte ratio & & & $4.26 \pm 4.19$ & & & $2.47 \pm 1.12$ & 0.165 \\
\hline Eosinophil & & & $0.146 \pm 0.29$ & & & $0.157 \pm 0.12$ & $0.011^{*}$ \\
\hline
\end{tabular}


The mean NLR values were $4.26 \pm 4.19$ in Bell's palsy patients and the control group was $2.47 \pm 1.12$. The difference was not statistically significant ( $p>0.05$ ).

The mean eosinophil values of Bell's palsy patients were $0.146 \pm 0.29$ and $0.157 \pm 0.12$ in the control group. The mean eosinophil values in patients with Bell's palsy were significantly lower than in the control group $(\mathrm{p}<0.05)$.

Statistically significant parameters were evaluated in terms of patient's recovery time. Significant differences were not observed in terms of recovery time between four parameters ( $p>0.05)$. Statistical analysis of recovery times of the patients are shown in Table 2 .

\section{DISCUSSION}

Bell's palsy is defined as a sudden paralysis/paresis of all muscles on one side of the face; dry eye; pain around the ear; altered sense of taste; hypersensitivity to sounds; or decreased tearing that is not associated with any other cranial neuropathy, ear, cerebellopontine or brainstem disease. ${ }^{[12]}$ It affects men and women equally. The highest incidence is in the 15 to 45 year old age group. ${ }^{[2]} \mathrm{A}$ complete recovery rate of $71 \%$ and an almost complete recovery rate of $84 \%$ are determined. ${ }^{[13]}$ The recovery rate in our study was $94 \%$. This higher rate of recovery can be explained in two ways. Firstly, diabetic patients were hospitalized during the steroid treatment and secondly, the follow-up periods in prior studies were shorter than ours. Recurrence occurs in $8 \%$ of Bell's palsy patients. Our study was consistent with the literature. In our study, four patients (8\%) showed recurrence. ${ }^{[14,15]}$

Recovery rate of Bell's palsy without treatment is reported as $70 \%{ }^{[16]}$ This rate reaches $90 \%$ with steroid treatment. ${ }^{[17]}$ Antiviral treatment is added to steroids in the treatment protocol of Bell's palsy after viral agents especially HSV are put forward as etiologic factors.
Although some studies stated that antiviral treatment has low efficiency, ${ }^{[18,19]}$ there are many studies stating that they lead to a better prognosis in early stages. ${ }^{[20,21]}$ In a review including 10 controlled randomized trials, antivirals combined with corticosteroids, reduce the risk of incomplete recovery of Bell's palsy more than corticosteroids alone. ${ }^{[22]}$ In adults, there are many studies about the standard protocol of corticosteroids but in children this protocol is still under debate. In many studies corticosteroids are recommended for three days from the onset of symptoms and antiviral agents are added if symptoms persist or there is a suspicion of viral infection. ${ }^{[23]}$ We also applied steroids combined with antivirals and this led to a recovery rate of $94 \%$. This result seems to support the efficacy of early antiviral treatment.

In our study, only three patients showed permanent facial paralysis. Statistical analysis was not possible because this number of patient was insufficient.

Bell's palsy is the most common disorder affecting facial nerves and is responsible for about $80 \%$ of all facial mononeuropathies. ${ }^{[2]}$ Although it is commonly seen, the etiology is not yet clear. There have been many theories put forward from an etiological aspect. These theories include the theory of viral infections, immunological factors, microcirculation failure theory, genetic and ischemic causes.

In terms of infections: Borrelia Burgdorferi and Herpes Zoster virus have been proven to cause facial palsy. Associations with several infectious pathogens, such as cytomegalovirus, Epstein-Barr virus, mumps, rubella and human immunodeficiency virus have also been documented. ${ }^{[12]}$ Among immunological mechanisms, Aviel et al. ${ }^{[25]}$ found changes in lymphocyte subsets in peripheral blood at acute phase. Following the description by Abramsky et al. ${ }^{[26]}$ of immunemediated mechanisms against the basic myelin protein in the disease's pathogenesis, cellular and humoral

Table 3

Statistical analysis of recovery times of patients

\begin{tabular}{|c|c|c|c|c|c|}
\hline & $\begin{array}{c}\text { Group } 1 \quad(n=23) \\
(0-29 \text { day }) \\
\end{array}$ & $\begin{array}{c}\text { Group } 2 \text { ( } n=16) \\
(30-89 \text { day }) \\
\end{array}$ & $\begin{array}{l}\text { Group } 3(n=6) \\
(3-6 \text { month) } \\
\end{array}$ & $\begin{array}{c}\text { Group } 4(\mathrm{n}=3)^{*} \\
\text { (non-healing) } \\
\end{array}$ & \\
\hline & Mean \pm SD & Mean \pm SD & Mean \pm SD & Mean $\pm S D$ & $p$ \\
\hline Platelet count & $297.91 \pm 124.04$ & $263.56 \pm 72.58$ & $207.67 \pm 73.961$ & - & 0.130 \\
\hline Plateletcrit & $0.241 \pm 0.085$ & $0.213 \pm 0.045$ & $0.181 \pm 0.05$ & - & 0.240 \\
\hline Neutrophil & $6.143 \pm 2.26$ & $7.59 \pm 4.97$ & $7.53 \pm 4.13$ & - & 0.775 \\
\hline Eosinophil & $0.2 \pm 0.37$ & $0.11 \pm 0.22$ & $0.05 \pm 0.05$ & - & 0.350 \\
\hline
\end{tabular}


immunologic alterations have been reported in adult patients with Bell's palsy.

Microcirculatory failure theory is another theory proposed in pathogenesis of Bell's palsy. ${ }^{[27]}$ In recent studies, NLR in cardiovascular diseases has been extensively studied and appears to be a significant marker of inflammation. ${ }^{[9,10]}$ Based on microcirculatory theory, the NLR ratio is expected to also be high in Bell's palsy and only a few studies have taken place pertain ring to this issue. ${ }^{[11,28]}$ In our study, NLR were studied in Bell's palsy patients, however in contrast to other studies it was not elevated. The reason for this is NLR in large vessel diseases are high and it may be normal in microangiopathic diseases.

In this study, among inflammation and thrombosis markers, PLT, PDW, PCT and MPV values were also examined. The PLT and PCT values were found to be significantly higher. The PDW value was slightly higher but not statistically significant. These values seem to support the thrombosis hypothesis for Bell's palsy. In Bell's palsy patients, these values are similar before and after disease onset, roughly speaking these patients are prone to thrombosis. Further studies should include whether it is useful and whether this addition will contribute to prognosis.

Neutrophil ratio was significantly increased in these patients. This is an indication of acute inflammation and bacterial infection. In the etiology of Bell's palsy, also Lyme disease which has been treated with antibiotics should be kept in mind. ${ }^{[29]}$

Eosinophil counts were also found to be significantly lower in these patients. Low eosinophils show acute inflammatory response. Bass et al. ${ }^{[30]}$ have argued that depending on chemotactic factors that were released on the condition of inflammation, eosinophils immigrate from circulation to inflammation fields. Another known reason of eosinophils is intense stress and the height of cortisol levels in the body. It is unknown whether lower eosinophils in Bell's palsy leads to acute inflammation or intense stress or both. In spite of this, there are some elements that restrict our study. These elements are the small number of patients and the fact that the study took place in a single center. Also the low number of patients who did not heal and as a result were unable to have their prognosis evaluated.

In conclusion, in this study, NLR, PLT, PCT, PDW, MPV values and their significance in predicting the recovery time from Bell's palsy were investigated. The PLT, PCT and neutrophil counts in patients with Bell's palsy were found to be significantly higher, eosinophil counts were found significantly lower than controls.
These values give us information about inflammation and thus cannot be used as a marker for predicting recovery time.

\section{Declaration of conflicting interests}

The authors declared no conflicts of interest with respect to the authorship and/or publication of this article.

\section{Funding}

The authors received no financial support for the research and/or authorship of this article.

\section{REFERENCES}

1. Betts TD, Dakers ST. Re: McCaulJA, Cascarini L, Godden D, Coombes D, Brennan PA, Kerawala C. Evidence based management of Bell's palsy. Br J Oral Maxillofac Surg 2014;52:990.

2. Holland NJ, Weiner GM. Recent developments in Bell's palsy. BMJ 2004;329:553-7.

3. Tekgul H, Polat M, Serdaroğlu G, Ikizoğlu T, Yalaz M, Kutukculer N, et al. Lymphocyte subsets in Bell's palsy: immune pathogenesis and outcome prediction. Pediatr Neurol 2004;31:258-60.

4. Yilmaz M, Tarakcioglu M, Bayazit N, Bayazit YA, Namiduru M, Kanlikama M. Serum cytokine levels in Bell's palsy. J Neurol Sci 2002;197:69-72.

5. Kumagai S, Tokuno J, Ueda Y, Marumo S, Shoji T, Nishimura T, et al. Prognostic significance of preoperative mean platelet volume in resected non-small-cell lung cancer. Mol Clin Oncol 2015;3:197-201.

6. Arruda-Olson AM, Reeder GS, Bell MR, Weston SA, Roger VL. Neutrophilia predicts death and heart failure after myocardial infarction: a community-based study. Circ Cardiovasc Qual Outcomes 2009;2:656-62.

7. Özgehan G, Kahramanca Ş, Kaya İO, Bilgen K, Bostanci $H$, Güzel H, et al. Neutrophil-lymphocyte ratio as a predictive factor for tumor staging in colorectal cancer. Turk J Med Sci 2014;44:365-8.

8. Cavuş UY, Yildirim S, Sönmez E, Ertan C, Ozeke O. Prognostic value of neutrophil/lymphocyte ratio in patients with pulmonary embolism. Turk J Med Sci 2014;44:50-5.

9. Ozyurtlu F, Yavuz V, Cetin N, Acet H, Ayhan E, Isik T. The association between coronary slow flow and platelet distribution width among patients with stable angina pectoris. Postepy Kardiol Interwencyjnej 2014;10:161-5.

10. Zhang GY, Chen M, Yu ZM, Wang XD, Wang ZQ. Relation between neutrophil-to-lymphocyte ratio and severity of coronary artery stenosis. Genet Mol Res 2014;13:9382-9.

11. Özler GS, Günak G. Neutrophil-lymphocyte ratio: a new predictive and prognostic factor in patients with Bell palsy. J Craniofac Surg 2014;25:944-5.

12. Greco A, Gallo A, Fusconi M, Marinelli C, Macri GF, de Vincentiis M. Bell's palsy and autoimmunity. Autoimmun Rev 2012;12:323-8. 
13. Peitersen E. The natural history of Bell's palsy. Am J Otol 1982;4:107-11.

14. Gilden DH. Clinical practice. Bell's Palsy. N Engl J Med 2004;351:1323-31.

15. Morris AM, Deeks SL, Hill MD, Midroni G, Goldstein WC, Mazzulli T, et al. Annualized incidence and spectrum of illness from an outbreak investigation of Bell's palsy. Neuroepidemiology 2002;21:255-61.

16. Peitersen E. Bell's palsy: the spontaneous course of 2,500 peripheral facial nerve palsies of different etiologies. Acta Otolaryngol Suppl 2002;549:4-30.

17. Salinas RA, Alvarez G, Daly F, Ferreira J. Corticosteroids for Bell's palsy (idiopathic facial paralysis). Cochrane Database Syst Rev 2010;3:001942.

18. van der Veen EL, Rovers MM, de Ru JA, van der Heijden GJ. A small effect of adding antiviral agents in treating patients with severe Bell palsy. Otolaryngol Head Neck Surg2012;146:353-7.

19. Lockhart P, Daly F, Pitkethly M, Comerford N, Sullivan F. Antiviral treatment for Bell's palsy (idiopathic facial paralysis). Cochrane Database Syst Rev 2009;4:001869.

20. Marsk E, Hammarstedt L, Berg T, Engström M, Jonsson L, Hultcrantz M. Early deterioration in Bell's palsy: prognosis and effect of prednisolone. Otol Neurotol 2010;31:1503-7.

21. Hato N, Matsumoto S, Kisaki H, Takahashi H, Wakisaka $\mathrm{H}$, Honda N, et al. Efficacy of early treatment of Bell's palsy with oral acyclovir and prednisolone. Otol Neurotol 2003;24:948-51.

22. Hernandez JM, Sherbino J. Do Antiviral Medications Improve Symptoms in the Treatment of Bell's Palsy? Ann
Emerg Med 2016 Jun 25.

23. Ciorba A, Corazzi V, Conz V, Bianchini C, Aimoni C. Facial nerve paralysis in children. World J Clin Cases 2015;3:973-9.

24. Zandian A, Osiro S, Hudson R, Ali IM, Matusz P, Tubbs $\mathrm{SR}$, et al. The neurologist's dilemma: a comprehensive clinical review of Bell's palsy, with emphasis on current management trends. Med Sci Monit 2014;20:83-90.

25. Aviel A, Ostfeld E, Burstein R, Marshak G, Bentwich Z. Peripheral blood $\mathrm{T}$ and $\mathrm{B}$ lymphocyte subpopulations in Bell's palsy. Ann Otol Rhinol Laryngol 1983;92:187-91.

26. Abramsky O, Webb C, Teitelbaum D, Arnon R. Cellmediated immunity to neural antigens in idiopathic polyneuritis and myeloradiculitis. Clinical-immunologic classification of several autoimmune demyelinating disorders. Neurology 1975;25:1154-9.

27. Bibas T, Jiang D, Gleeson J. Disorders of the facial nerve. In: Gleeson M, editor. Scott-Brown's Otorhinolaryngology Head and Neck Surgery. 7th ed. London: Edward Arnold; 2008. p. 3883-6.

28. Bucak A, Ulu S, Oruc S, Yucedag F, Tekin MS, Karakaya F, et al. Neutrophil-to-lymphocyte ratio as a novel-potential marker for predicting prognosis of Bell palsy. Laryngoscope 2014;124:1678-81.

29. Tiemstra JD, Khatkhate N. Bell's palsy: diagnosis and management. Am Fam Physician 2007;76:997-1002.

30. Bass DA, Gonwa TA, Szejda P, Cousart MS, DeChatelet LR, McCall CE. Eosinopenia of acute infection: Production of eosinopenia by chemotactic factors of acute inflammation. J Clin Invest 1980;65:1265-71. 